\title{
Functional groups in a semideciduous seasonal forest in Southeastern Brazil
}

\author{
Vagner Santiago do Vale * \\ Ivan Schiavini \\ Sérgio de Faria Lopes \\ Ana Paula de Oliveira \\ Olavo Custódio Dias Neto \\ André Eduardo Gusson \\ Universidade Federal de Uberlândia, Campus Umuarama \\ CEP 38400-902, Uberlândia - MG, Brazil \\ * Autor para correspondência \\ vsvale@hotmail.com
}

Submetido em 17/05/2012

Aceito para publicação 11/01/2013

\section{Resumo}

Grupos funcionais em floresta estacional semidecidual no sudeste do Brasil. Este estudo foi realizado em uma floresta semidecidual no sudeste do Brasil. Cinco atributos ecológicos foram utilizados para definir os grupos funcionais: estrato predominante da espécie, exigência de luminosidade da planta, dispersão de sementes, provável polinizador e deciduidade. Os grupos foram formados através de uma matriz de espécies e seus atributos e foram delimitados de acordo com o índice de similaridade de Jaccard e um dendrograma gerado pela média do grupo (UPGMA). A análise utilizada foi satisfatória, indicando a formação de quatro grupos coerentes com distintas funções para a comunidade e o ecossistema. Os resultados indicam uma comunidade arbórea em estágio tardio de sucessão, com relações entre espécies da flora e fauna.

Palavras-chave: Estratificação; Deciduidade; Polinização; Síndrome de dispersão; Tolerância à sombra

\section{Abstract}

This study was carried out in a semideciduous forest in Southeastern Brazil. Five ecological attributes were used to define the functional groups: dominant stratum of the species, light demand of the plant, seed dispersal, likely pollinator, and deciduousness. The groups were formed through a species matrix and its attributes, and they were delimited according to the Jaccard similarity coefficient and a dendrogram generated by the group average (UPGMA). The analysis used was satisfactory, indicating the formation of four coherent groups with distinct functions both with regard to the community and the ecosystem. The results indicate a tree community in a late successional stage, with relations between flora and fauna species.

Key words: Dispersal syndrome; Deciduousness; Pollination; Shade tolerance; Stratification 


\section{Introduction}

Seasonal semideciduous forests (SSFs) occur in several tropical regions, on soils with different degrees of fertility, and they partially respond to the seasonal climate, especially in locations where the rainy and dry seasons are well marked (PENNINGTON et al., 2009; OLIVEIRAFILHO; RATTER, 2002). Several works have shown the high diversity and heterogeneity among these forests in the Southeastern Region of Brazil, combined with a high beta diversity, even among close areas (OLIVEIRA-FILHO; FONTES, 2000; LOPES et al., 2012). Low floristic similarity observed between SSFs makes it difficult to understand the role played by each species for maintaining the ecosystem of a certain area.

Especially in tropical forests, some species are very dense and crucial to ecosystem maintenance, whereas others are transient and rare, and their loss wouldn't cause serious damage to the community (WALKER, 1992) - these species should be further studied. However, a large number of these species have similar characteristics or similar resource use, and they play the same role in the ecosystem (MÉDAIL et al., 1998).

Classification into functional groups (FGs) can reduce a lot of species to a small set of functional types, which includes disturbance responses or similarity in terms of dispersal, competition, and survival processes (WALKER, 1992; MÉDAIL et al., 1998). The use of FGs is particularly important because, for many aspects of ecosystem performance, the functional diversity is more important than the species diversity (PENDRY et al., 2007; POWERS; TIFFIN, 2010). However, plants have several attributes which can be used for FG identification (PENDRY et al., 2007), and the choice of attributes should be clearly related to species functions within the community.

For instance, plant attributes related to fauna represent a clear role for the forest system's maintenance. Animal-plant interactions, such as pollination and dispersal processes, are priority targets for biodiversity conservation, their importance is due to regenerative processes, fauna diversity maintenance, and ecosystem functions (CORDEIRO; HOWE, 2001; KREMEN, 2005). Therefore, seed dispersal and pollination syndromes are among the first steps to form vegetation species groups, as reported in recent studies (KINOSHITA et al., 2006; YAMAMOTO et al., 2007). This concept is particularly important with regard to animals, because it demonstrates the potential of flora to provide resources for their pollinators and seed dispersers and, thus, maintain the local wildlife (KINOSHITA et al., 2006).

Different animal groups occupy distinct positions on the vertical space in a forest. Vertebrate species, especially birds, mammals (PEARSON, 1971; CLARK; POULSEN 2001), and invertebrates (HOWE; SMALLWOOD, 1982) may prefer to occupy different forest layers. This preference is often related to the attributes of trees, such as the abundance of resources, temperature, density of leaves, and luminosity (RICHARDS, 1996; WALTHER et al., 1999).

Other factors influence on forest maintenance and regenerative processes. Abiotic factors, such as luminosity, combined with canopy coverage, regulate the light available in the lower layers, determining growth and seedling (RICHARDS, 1996). Plant species, however, vary in their growth responses under high luminosity and their mortality under shade (PEARSON et al., 2003). Some species are adapted to survive in patches with high direct sunlight, such as natural gaps (PEARSON et al., 2003). These species are regarded as light-demanding species and they have a clearly different function from that of shade-tolerant species in terms of regeneration after treefall gap.

Deciduousness is another important process related to luminosity, because the leafless phase opens the canopy, increases light incidence on the understory, and facilitates the regeneration process in a forest (GANDOLFI et al., 2007). However, this seasonal phenomenon differs from natural gaps because it occurs every year in defined seasons, immediately influencing trees under the canopy of deciduous species. Since deciduous species in forests usually present a fast growth (CORNELISSEN et al., 1996) and canopy trees can reach a large size, they reach the canopy and tend to affect most individuals of the subcanopy and understory. On the other hand, evergreen species tend to produce and retain leaves throughout the year, and the establishment of light demanding species located under these evergreen species could be difficult. 
Having in mind the importance of SSFs and the need for further studies on ecological models across high-diversity tropical forest systems, this paper aims to: (1) evaluate, using a set of selected attributes, the cohesive plants' functional groups in a seasonal forest in southeastern Brazil; and 2) analyze the importance of each functional group within the ecosystem context. The plant community studied presents a good conservation status (VALE et al., 2009), thus, our central hypothesis is that mature forests must support a high variety of tree FGs, potential suppliers of resources to local wildlife, and they present a good potential for their self-maintenance.

\section{Material and Methods}

The study was carried out in a private property named "Fazenda da Mata", located in the city of Araguari, Minas Gerais, Brazil, between the coordinates $18^{\circ} 29^{\prime} 28^{\prime \prime} \mathrm{S} 48^{\circ} 22^{\prime} 36^{\prime \prime} \mathrm{W}$ and $18^{\circ} 30^{\prime} 23^{\prime \prime} \mathrm{S}, 48^{\circ} 23^{\prime} 45^{\prime \prime} \mathrm{W}$. The farm has a forest of about 200ha, comprising a gradient of deciduous forest on steep slopes, gallery forest close to watercourses, and a SSF between these formations. The regional climate is Aw Megathermic, according to the Köppen classification system (KÖPPEN, 1948), characterized by dry winter and rainy summer, with a $18^{\circ} \mathrm{C}$ average annual temperature and rainfall about 1,595mm/year (SANTOS; ASSUNÇÃO, 2006). The terrain presents strong inclination from the plateau top until the gallery forest valley, with a variation of $190 \mathrm{~m}$ in altitude $(830 \mathrm{~m}$ to $640 \mathrm{~m}$ a.s.1.). The SSF soil is eutrophic, with high concentrations of $\mathrm{Mg}, \mathrm{K}$, and $\mathrm{Ca}$ and high $\mathrm{pH}$ value (VALE et al., 2009). The forest presents an excellent conservation status and it may be regarded as one of the largest continuous forests in the region (LOPES et al., 2012).

\section{Vegetation sampling and ecological attributes}

Data from the tree component structure measures conducted in 2007 were used (VALE et al., 2009), which sampled all living trees with circumference at breast height $(\mathrm{CBH})$, i.e. $1,30 \mathrm{~m}$, equal to or greater than
$15 \mathrm{~cm}$ in a hectare of forest; these measures followed the instructions from Felfili et al. (2005). From 79 tree species identified in the previous work (Vale et al., 2009), were used in this analysis 43 species which had, at least, 5 individuals.

The ecological strategies of the SSF species were defined having five attributes as a basis: dispersal syndrome, pollination syndrome, shade tolerance, deciduousness, and reproductive stratum. Information on the ecological attributes was obtained through a survey on scientific papers and specialized books, as well as field observations, consultations with experts, and previous analyses of the tree community structure (VALE et al., 2009).

The dispersal syndromes were classified into the following categories (according to PIJL, 1982): (1) anemochoric; (2) autochoric; (3) ornitochoric (diaspores dispersed by birds); (4) mammaliochoric (diaspores dispersed by non-flying mammals); and (5) chiropterocoric (seed or fruit dispersed by bats). Regarding the pollination syndrome, the species were classified according to the potential animal pollinator: (1) very small insects; (2) big bees; (3) moths; (4) butterflies; (5) mammals; (6) wind; and (7) small insects (bees, flies, and wasps) (OLIVEIRA; GIBBS, 2000).

In terms of deciduousness, the species were classified as: (1) deciduous (species which lose all leaves at some time in the dry season, thus, some possible brevideciduous species which lose their foliage for a brief period of the year were include here); or (2) evergreen species (species which retain leaves throughout the year, thus, species which are regarded by some authors as "semideciduous", because the trees of these species don't lose all leaves along the year, indeed, were include here). Regarding shade tolerance, the species were classified, having Vale et al. (2009) as a basis, as: (1) direct light demanding species, i.e. more than $70 \%$ of the individuals are located above other species and receive direct sunlight; or (2) shade-tolerant species, i.e. at least $50 \%$ of individuals were sampled under the canopy of other trees. Here, one assumes that, if half of the trees are found under diffuse sunlight, this species is able to survive under the shade of other trees. The species with at least $70 \%$ of individuals sampled under direct 
sunlight were classified as direct light demanding ones, without the shading influence of other trees. The species with $50 \%$ to $70 \%$ of trees receiving direct sunlight were classified by means of observation and the authors' field experience with regard to their occurrence in the study area (VALE et al., 2009) and in similar areas.

In order to classify the stratum, the species were grouped into: (1) typical of canopy; (2) subcanopy; and (3) typical of understory (see methodology in VALE et al., 2009). This method focuses on the species reproductive stratum, for instance, species regarded as typical of the canopy may have individuals in lower strata, but most adult reproductive trees are found on the canopy.

\section{Data analysis}

A presence/absence matrix of species and their ecological attributes was made. For each attribute, the columns were unique. The functional groups were revealed through clustering techniques, defined through the Jaccard coefficient and distance values obtained in the dendrogram generated by the group average (UPGMA). This technique is widely used to form functional groups and it's regarded as effective (PETCHEY; GASTON, 2002). The cophenetic correlation of the dendrograms generated was calculated; the coefficient of cophenetic correlation (equivalent to the Pearson coefficient) was used as a concordance measure among the clustering obtained and the original matrix of distances (BUSSAB; MORETTIN, 2003). After using the dendrogram of groups' formation, a Multi-Response Permutation Procedure (MRPP) was made through the Jaccard coefficient similarity as a coefficient of distances between all groups with the PcORD v. 6 software (McCUNE; MEFFORD, 2011). However three species didn't form a group with any other in the dendrogram, thus, the MRPP was used with the remaining 40 species. This is a technique for detecting the difference between $a$ priori classified groups. All other analysis were performed using the FITOPAC SHELL program (SHEPHERD, 2004).

\section{Results}

The 43 tree species (Table 1) used during the analysis totaled only $54.42 \%$ of species found by Vale et al. (2009), although $91.30 \%$ of individuals sampled in the study area were comprised. These values represent $87.94 \%$ of the importance value (see VALE et al., 2009); then, in all analyses made here, a significant portion of the community was represented.

Two major groups were found, one formed by direct-light demanding species (with the exception of Cryptocarya aschersoniana $\mathrm{Mez}$ ) and another with only shade-tolerant species (Figure 1). These groups were subdivided into groups with similarity over 0.5 , representing species with at least three common characteristics and they had, at least, $50 \%$ of similar functional traits in this community.

Thus, four major functional groups were delimited (Table 2): G1, made up by direct-light species, ornitochoric, and pollinated by small insects; G2, made up by species with dispersal by mammals (flying or non-flying), pollinated by small insects, evergreen and located in the canopy; G3, direct-light species with abiotic dispersal (anemochory or autochory), deciduous, and located in the canopy; and G4, shade-tolerant, ornitochoric, and evergreen species (Figure 1). G3 and G4 were subdivided, retrospectively, into grouping species with recognized distinct roles in vegetation, the first by seed dispersal and the second by stratum classification.

Other species didn't belong to any of the groups mentioned above. Inga marginata Willd. and I. vera Willd. formed an independent group, with more than $50 \%$ of similarity. The same occurred with Aspidosperma polyneuron Mull. Arg. and Simira sampaioana (Stand1.) Steyerm. These groups were classified as "isolated groups", without high similarity with the other groups. The differences between these six main groups (G1, G2, G3, G4, GI1, and GI2) were determined through MRPP analysis (made without species which didn't form groups), and one may reject the null hypothesis with regard to no difference among groups $(\mathrm{T}=-14.17$, $\mathrm{A}=0.48, \mathrm{p}<0.001)$. The " $\mathrm{A}$ " value is "within-group agreement" and the maximum possible value is 1.00 when all items are identical within groups and zero when heterogeneity within groups equals expectation by chance, and, then, the groups had a medium-high agreement. Furthermore, only GI1 and GI2 were 
regarded as similar by MRPP (see further information in the appendix), and all other pairwise comparisons showed differences among all groups formed through the dendrogram. The MRPP shows no difference in GI1 and GI2, perhaps, because these groups were formed by only two species (then weak groups in terms of number of species) and indicates that these groups are two isolated groups. This means that other works with more species in other areas may confirm the existence of these groups as separate ones. In fact, GI1 and GI2 are distinct, mainly due to differences on light demand, seed dispersal, and deciduousness (Table 2).

Acalypha gracilis Spreng., Calliandra foliolosa Benth., and Quararibea turbinata (Sw.) Poir. didn't form groups and they're discussed separately. These seven species remained outside of the four major groups and they represent only $7.05 \%$ of the 766 individuals analyzed. The cophenetic correlation was 0.82 ; then, the cluster was able to demonstrate the correlation between the distance matrix and the original matrix.

TABLE 1: List of semideciduous tree species in Fazenda da Mata (Araguari, MG, Brazil) used in the analysis of functional groups, with regard to the number of sampled individuals $(\mathrm{N})$ and attributes.

\begin{tabular}{|c|c|c|c|c|c|c|}
\hline Species & $\mathbf{N}$ & Light Demand & Seed Dispersal & Deciduousness & Pollinator & Stratum \\
\hline Acacia polyphylla DC. & 15 & Direct light & Autochoric & Deciduous & Small insects & Canopy \\
\hline Acalypha gracilis Spreng. & 6 & Shade-tolerant & Autochoric & Evergreen & Wind & Understory \\
\hline Albizia polycephala (Benth.) Killip & 6 & Direct light & Anemochoric & Deciduous & Small insects & Canopy \\
\hline Alchornea glandulosa Poepp. & 18 & Direct light & Ornitochoric & Evergreen & Small insects & Canopy \\
\hline Allophylus racemosus Sw. & 6 & Direct light & Ornitochoric & Evergreen & Small insects & Understory \\
\hline Apuleia leoicarpa (Vogel) J.F. Macbr. & 11 & Direct light & Anemochoric & Deciduous & Big bees & Canopy \\
\hline Aralia warmingiana (Marchal) J. Wen & 5 & Direct light & Ornitochoric & Deciduous & Small insects & Canopy \\
\hline Ardisia ambigua Mart. & 13 & Shade-tolerant & Ornitochoric & Evergreen & Small insects & Understory \\
\hline Aspidosperma polyneuron Mull. Arg. & 6 & Shade-tolerant & Anemochoric & Deciduous & Moths & Subcanopy \\
\hline Calliandra foliolosa Benth. & 5 & Shade-tolerant & Autochoric & Evergreen & Moths & Subcanopy \\
\hline Calyptranthes widgreniana O. Berg. & 5 & Shade-tolerant & Ornitochoric & Evergreen & Small insects & Understory \\
\hline Cariniana estrellensis (Raddi) Kuntze & 12 & Direct light & Anemochoric & Deciduous & Big bees & Canopy \\
\hline Casearia gossypiosperma Briq & 13 & Direct light & Anemochoric & Deciduous & Small insects & Canopy \\
\hline Ceiba speciosa (A.St.-Hil.) Ravena & 10 & Direct light & Anemochoric & Deciduous & Butterflies & Canopy \\
\hline Chomelia sericea Mull. Arg. & 7 & Shade-tolerant & Ornitochoric & Evergreen & Big bees & Understory \\
\hline $\begin{array}{l}\text { Chrysophyllum gonocarpum (Mart. \& } \\
\text { Enclher ex Miq.) Engl. }\end{array}$ & 30 & Shade-tolerant & Ornitochoric & Evergreen & Very small insects & Understory \\
\hline Cordia superb Cham & 13 & Direct light & Mammaliochoric & Evergreen & Small insects & Canopy \\
\hline Cryptocarya aschersoniana $\mathrm{Mez}$ & 6 & Shade-tolerant & Mammaliochoric & Evergreen & Small insects & Canopy \\
\hline Eugenia florida DC. & 170 & Shade-tolerant & Ornitochoric & Evergreen & Small insects & Subcanopy \\
\hline Eugenia involucrate DC. & 27 & Shade-tolerant & Ornitochoric & Evergreen & Small insects & Understory \\
\hline Guapira venosa (Choisy) Lundell & 6 & Shade-tolerant & Ornitochoric & Evergreen & Small insects & Subcanopy \\
\hline Guarea guidonia (L.) Sleumer & 14 & Shade-tolerant & Ornitochoric & Evergreen & Butterflies & Canopy \\
\hline Guarea kunthiana A. Juss & 17 & Shade-tolerant & Ornitochoric & Evergreen & Butterflies & Subcanopy \\
\hline Guazuma ulmifolia Lam. & 8 & Direct light & Mammaliochoric & Evergreen & Small insects & Canopy \\
\hline Inga marginata Willd. & 10 & Direct light & Mammaliochoric & Evergreen & Moths & Understory \\
\hline Inga vera Willd. & 12 & Direct light & Mammaliochoric & Evergreen & Moths & Subcanopy \\
\hline
\end{tabular}




\begin{tabular}{|c|c|c|c|c|c|c|}
\hline $\begin{array}{l}\text { Lonchocarpus cultratus (Vell.) A. M. } \\
\text { G. Azevedo \& H. C. Lima }\end{array}$ & 7 & Direct light & Anemochoric & Deciduous & Big bees & Canopy \\
\hline Margaritaria nobilis L.F & 6 & Direct light & Autochoric & Deciduous & Small insects & Canopy \\
\hline Metrodorea stipularis Mart. & 7 & Shade-tolerant & Ornitochoric & Evergreen & Small insects & Canopy \\
\hline Miconia latecrenata Triana & 6 & Direct light & Ornitochoric & Evergreen & Small insects & Subcanopy \\
\hline $\begin{array}{l}\text { Nectandra megapotamica (Spreng.) } \\
\text { Mez }\end{array}$ & 12 & Shade-tolerant & Ornitochoric & Evergreen & Very small insects & Subcanopy \\
\hline Psidium sartorianum (O.Berg) Nied. & 22 & Direct light & Chiropterochoric & Evergreen & Small insects & Canopy \\
\hline Quararibea turbinate (Sw.) Poir. & 5 & Shade-tolerant & Chiropterochoric & Evergreen & $\begin{array}{l}\text { Non-flying } \\
\text { mammal }\end{array}$ & Canopy \\
\hline Rhamnidium elaeocarpum Reissek & 6 & Direct light & Ornitochoric & Deciduous & Small insects & Subcanopy \\
\hline Simira sampaioana (Standl.) Steyerm. & 10 & Shade-tolerant & Anemochoric & Deciduous & Small insects & Subcanopy \\
\hline Sweetia fruticosa Spreng. & 10 & Direct light & Anemochoric & Deciduous & Small insects & Canopy \\
\hline Trichilia catigua A. Juss. & 77 & Shade-tolerant & Ornitochoric & Evergreen & Small insects & Subcanopy \\
\hline Trichilia clausseni C. DC. & 92 & Shade-tolerant & Ornitochoric & Evergreen & Small insects & Subcanopy \\
\hline Trichilia elegans A. Juss. & 19 & Shade-tolerant & Ornitochoric & Evergreen & Small insects & Subcanopy \\
\hline Unonopsis lindmanii R. E. Fr. & 8 & Shade-tolerant & Ornitochoric & Evergreen & Small insects & Subcanopy \\
\hline $\begin{array}{l}\text { Urera baccifera (Jacq.) Gaudich. Ex } \\
\text { Griseb. }\end{array}$ & 10 & Direct light & Ornitochoric & Deciduous & Small insects & Understory \\
\hline Zanthoxylum riedelianum Engl. & 9 & Direct light & Ornitochoric & Deciduous & Small insects & Subcanopy \\
\hline Zollernia ilicifolia (Brongn.) Volgel & 9 & Direct light & Autochoric & Deciduous & Not classified & Canopy \\
\hline
\end{tabular}

FIGURE 1: Functional groups formed having traits of species from a semideciduous forest in Central Brazil as a basis.

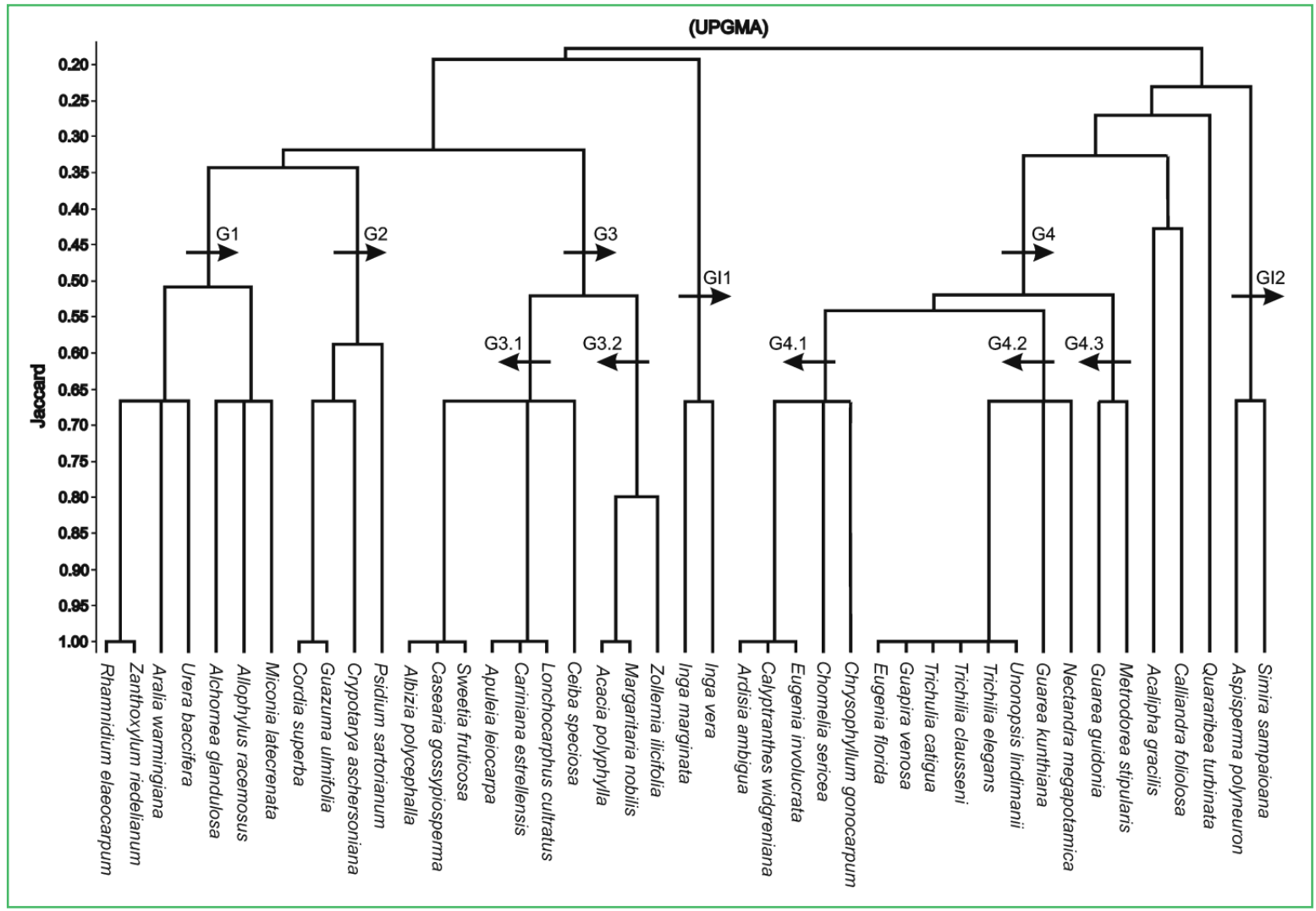


TABLE 2: Functional groups formed with tree species from the seasonal semideciduous forest of Southeastern Brazil (Araguari, MG, Brazil), having the matrix of ecological attributes indicated in Table 1 and grouping analysis as a basis. $\mathrm{N}=$ number of individuals. The last column indicates the percentage of individuals in the group.

Functional Groups and Species

\begin{tabular}{l} 
Functional Groups and Species \\
\hline Group 1 \\
Rhamnidium elaeocarpum, Zanthoxylum riedelianum, Aralia \\
warmingiana, Urera baccifera, Alchornea glandulosa, \\
Allophylus racemosus, and Miconia latecrenata
\end{tabular}

\section{Group 2}

Cordia cf. superba, Guazuma ulmifolia aschersoniana, and Psidium sartorianum

\section{Grupo 3}

Subgroup 3.1: Casearia gossypiosperma, Albizia polycephalla, Sweetia fruticosa, Apuleia leiocarpa and Direct light, anemochorics, deciduous, typical of Cariniana estrellensis, Lonchocarpus cultratus, and Ceiba canopy. speciosa

Subgroup 3.2: Acacia polyphylla, Margaritaria nobilis, and Zollernia ilicifolia

\section{Group 4}

Subgroup 4.1: Ardisia ambigua, Calyptranthes widgreniana, Eugenia involucrata, Chomelia sericea, and Chrysophyllum gonocarpum

SubGroup 4.2: Eugenia florida, Guapira venosa, Trichilia catigua, Trichilia clausseni, Trichilia elegans, Shade-tolerant, ornitochoric, evergreen, typical of Unonopsis lindimanii, Guarea kunthiana, and Nectandra subcanopy. megapotamica

Subgroup 4.3: Guarea guidonia, and Metrodorea Shade-tolerant, ornitochoric, evergreen, typical of stipularis

Isolated Group 1: Inga vera, and Inga marginata canopy.

Direct light, mammaliochorics, evergreen, pollinated by moths, typical of subcanopy and understory.

Shade-tolerant, anemochorics, deciduous, typical of subcanopy.

Isolated Group 2: Simira sampaioana and Aspidosperma polyneuron

Shade-tolerant, ornitochoric, evergreen, predominantly pollinated by small insects, butterflies and very small insects, dominant in subcanopy and understory.

Shade-tolerant, ornitochoric, evergreen, typical of understory.

No Grouping Species: Acalipha gracilis, Calliandra foliolosa, and Quararibea turbinata 


\section{Discussion}

G1 - light-demanding, ornitochoric, deciduous or evergreen species, pollinated by small insects and with wide distribution in forest layers - represents $7.83 \%$ of species in the tree community. Rhamnidium elaeocarpum Reissek, Zanthoxylum riedelianum Engl., Aralia warmingiana (Marchal) J. Wen, and Urera baccifera (L.) Gaudich. ex Wedd are deciduous and Alchornea glandulosa Poepp., Miconia latecrenata Triana, and Allophylus racemosus Sw are evergreen species. An important characteristic of G1 is the presence of species located in three strata: $U$. baccifera and Allophylus racemosus Sw. in the understory, $Z$. riedelianum, $R$. elaeocarpum, and $M$. latecrenata in the subcanopy, and A. warmingiana and A. glandulosa in the canopy.

Although deciduous and evergreen species often occupy different habitat types (ANTUNEZ et al., 2001), the SSF provides favorable conditions for the establishment of these two plants types. There're deciduous and evergreen species in all forest layers with similar functions in the fauna. This also means that G1 species are able to interact with ornithofauna and small insect pollinators in all tree community heights. Pearson (1971), in a study on the vertical stratification of birds, detected that some species don't demonstrate any kind of stratification in a tropical dry forest in Peru and they can be found both in gaps and canopy, then, on patches with direct sunlight regardless of the layer. Although each layer has typical pollinators and seed dispersers (SMITH, 1973), this functional group favors the presence of generalist animals in different strata. It has already been observed that pollination by bees is most common in all vegetation strata and that pollination by flies follows the same pattern (KINOSHITA et al., 2006).

Four G1 species (R. elaeocarpum, A. warmingiana, A. glandulosa, and U. baccifera) were classified as pioneers (VALE et al., 2009); they're typical of open gaps in the forest, but sometimes they can reach the canopy (as it's the case of $A$. glandulosa and $A$. warmingiana). Thus, some bird species could use fruit resources in trees with similar luminosity in treefall gaps or in the canopy (ORIANS, 1969). Moreover, all G1 species are light-demanding and most of them were more frequently found under direct sunlight in the study area.

G2 species are light-demanding, mammaliochorous, evergreen, pollinated by small insects, and typical of canopy. Out of the species Cordia superba Cham, Cryptocarya aschersoniana Mez, Guazuma ulmifolia Lam. and Psidium sartorianum (O. Berg) Nied. only the latter is quiropterocchoric. This group represents only $6.90 \%$ of the individuals tested. However, it's a special group, since it's the only one which represents mammaliochorous species located in the canopy. Although primates are dominant on small and medium sized trees and they disperse the seeds of a great number of species below the subcanopy (CLARK; POULSEN, 2001), this dispersal syndrome in large trees suggests the presence of mammals.

This group is also entirely evergreen, like all other mammaliochoric species analyzed. Mammals can select both fruit type and tree characteristics. Animals try to avoid the strong daily sunshine typical of regions closer to the tropics, and evergreen species provide more shade with milder temperatures than a deciduous forest in the dry season. Different from deciduousness, fruit phenology in the tropics is aseasonal and fruit production isn't limited by droughts (MORELLATO et al., 2000). Thus, mammals may have two resource types available on the same evergreen tree: food and shelter from sunlight. The dominance of pollination syndrome due to a small insect was also remarkable in this group, as in G1. The prevalence of species pollinated by bees in the canopy has been reported in humid tropical forests, where $52 \%$ of the species are melittophilous (BAWA et al., 1985).

G3 comprises light-demanding, abiotic dispersal, deciduous species, predominantly pollinated by small insects and large bees, and they're typical of the canopy. Although five species are pollinated by small insects, other three are pollinated by large bees. This group was the only one pollinated by large bees, probably due to large bees foraging flowers of a reduced range of species (OLIVEIRA; GIBBS, 2000). Large bees are more frequently associated to canopy trees, when compared to the subcanopy and understory (BAWA et al., 1985), 
something which indicates that these insects apparently prefer foraging in the upper stratum.

Formed exclusively by canopy deciduous species, G3 may be regarded as a good biomass accumulator, because deciduous species have a higher relative growth rate when compared to evergreen species (CORNELISSEN et al., 1996). Deciduous species produce more biomass by photosynthesis in a shorter period of time and they can grow rapidly (CORNELISSEN et al., 1996), mainly in a seasonal environment, storing high amounts of organic matter.

Despite the similarities presented by G3 species, this group could be divided into two subgroups, based on different functional characteristics between anemochoric and autochoric species.

G3.1 is formed by six species, typically anemochorics. Plants dispersed by wind are relatively common with regard to number and proportion in dry environments (HOWE; SMALLWOOD, 1982), but they're still observed in humid forests. Most species dispersed by wind live in the forest canopy and they're more abundant in seasonal forests than in humid forests (HOWE; SMALLWOOD, 1982).

The occurrence of anemochory in tall trees may be associated to an increased exposure of diaspores to wind action and, thus, there're better dispersal chances (HOWE; SMALLWOOD, 1982; YAMAMOTO et al., 2007). The seasonal climate would also help in dispersal by wind, because there's a negative correlation between the percentage of species dispersed by wind in the canopy and the annual rainfall (HOWE; SMALLWOOD, 1982).

G3.2 is the only typical autochoric group, formed by only three canopy species. The frequency of autochoric individuals can be related to the forest's conservation degree, as pointed out by Toniato and Oliveira-Filho (2004). However, this dispersal syndrome isn't frequent in SSF, regardless of the conservation degree. Isolated fragments may be inaccessible to species with low dispersal capacity (MATLACK, 1994), and the seeds of autochoric species reach short distances (WILSON, 1992) and present low abundance (only $2.87 \%$ of individuals surveyed in the study area); then, this functional group may represent a stable group, not threatened in the SSF.

G4, unlike the previous three groups, is made up by shade-tolerant species. This group is typically ornitochoric and evergreen, with a greater richness and higher abundance. This group has a high diversification of pollinators: small insects (such as thrips), insects (wasps and flies), butterflies, and bees. This wide range of pollinators may have been influenced by the presence of species of this group in the three vegetation strata.

The presence of tiny insects (e.g. thrips) and butterflies as pollinators in $\mathrm{G} 4$ reflects the importance of each species to the local wildlife, since few species with these pollination types were found. G4 ornitochoric species sustain more than $65 \%$ of individuals in the community, being the largest producer of potential resources for birds in the SSF studied. Besides possessing the potential to produce many fruits, this group can sustain a great diversity of birds, because G4 occurs on all three layers of the vegetation (canopy, subcanopy, and understory). As observed by Pearson (1971), different bird species can occupy distinct positions in the vegetation, and the results of this study provide this idea with some evidence.

The exclusive presence of shade-tolerant species should also be highlighted. Species with high dispersal capacity are less susceptible to fragmentation than species with low dispersibility (LORD; NORTON, 1990). Therefore, the shade-tolerant species would be more sensitive to fragmentation of habitat than the directlight species (METZGER, 2000). Shade-tolerant species are more vulnerable to fragmentation effects and lack of connectivity between the fragments than the direct-light species (METZGER, 2000). Moreover, all shade-tolerant species of G4 are zoocoric; thus, a disturbance may not only affect this group, but the seed dispersers and many pollinators, too.

Since G4 species were found in all tree community layers, the group could be divided into G4.1 (understory), G4.2 (subcanopy), and G4.3 (canopy).

G4.1 is the single understory group, it represents $10.70 \%$ of the tree community. This subgroup comprises more than $70 \%$ of individuals and more than $85 \%$ 
of the shade-tolerant species in the understory. It's distinguished from the other groups because it represents small species, which germinate, grow, reproduce, and die in the shaded understory. Thus, the entire lifecycle occurs in the understory, and the group represents an indicator for disturbance. Other SSF areas, even those with distinct floristic composition, have shade-tolerant species typical of the understory, and, if the proportion of these individuals is lesser than $70 \%$, this indicates the occurrence of disturbance in the community, taking into account natural disturbances.

G4.2 is the most abundant subgroup of the tree community, because it's formed by the three most abundant species in the community (Eugenia florida DC., Trichilia catigua A. Juss., and Trichilia clausseni C. DC.). This group alone represents over $88 \%$ of individuals of the species typical of the subcanopy and over $52 \%$ of all individuals analyzed. Studies in tropical forests (ROTH, 1987) and seasonal forests (KILLEEN et al., 1998) have shown that zoocoric species are dominant in lower layers, under the canopy. As it represents more than half of the individuals analyzed, this is the "key group" in the community studied and it must undergo fewer structural modifications after disturbance, when compared to low abundant groups. Only largescale disturbances could cause negative effects in the community (OLIVEIRA-FILHO et al., 1997), being able to change the dominance of this subgroup. So, its abundant presence in this SSF should be maintained over time, if the current conservation status is maintained. Thus, unlike G4.1, the decrease of G4.2 would not only indicate the presence of strong disturbance in the area, but also changes in successional stage; the community would probably take a long time to recover and return to the current maturity status.

G4.3 contains only two species: Guarea guidonia and Metrodorea stipularis. This group also has few individuals and it doesn't represent the community as a whole, but it demonstrates the ability of shade-tolerant species to reach the canopy vegetation when they become reproductive. Studies on vertical stratification of birds have shown that birds in the forest's subcanopy perform extensive foraging, unlike birds of the canopy and understory (WALTHER, 2002). This would entail a diversification of ornitochoric functional groups: species which reach the canopy (G1 and G4.3) and species always present in the understory (G4.1).

Isolated groups (GI) were regarded as those which form cohesive groupings, but didn't show similarity above 0.5 with any other group. Two small isolated groups were formed:

1) GI1: a group formed by two species of the genus Inga (I. vera and I. marginata). Both species are direct light demanding and evergreen species, dispersed by mammals and they're usually found in the community lower layers. Unlike other groups, they're pollinated by moths. This is a common pollinator in the understory of humid tropical forests (BAWA et al., 1985). This group, as G2, is dispersed by mammals. However, the genus Inga is typical of the subcanopy and understory, implying that the GI1 can be dispersed by groups of mammals other than those of G2 (a canopy group). Moreover, while C. superba and G. ulmifolia have dry fruits and may require some sort of manipulation for feeding, Inga presents soft fruits that are easily opened, and even animals which are unable to manipulate can ingest them.

2) GI2: this group consists of Aspidosperma polyneuron, Simira sampaioana, anemochoric, and deciduous species, found in the subcanopy. Although they're species of subcanopy, due to the fall of leaves from the canopy, the dispersion of these species may occur without major losses. However, they may also be regarded as an exception among the anemochoric species (A. polyneuron is shadetolerant, but it still can grow to reach the canopy), or they must be located at certain sites with unique characteristics in vegetation ( $S$. sampaioana trees are concentrated in a single plot in the study area).

There are three isolated species, i.e. not joined with others: Acalipha gracilis Müll. Arg, Calliandra foliolosa Benth., and Quararibea turbinata (Sw.) Poir. A. gracilis is the only species pollinated through anemophily and Q. turbinata is pollinated by non-flying mammals. Both are shade-tolerant and autochoric. Although these three species don't form a consistent group, all of them are important for forest conservation; first, because they represent rare attribute combinations in the community, 
and second, because they're atypical SSF species in the region where the study was carried out. The three species are found in studies conducted in the non-seasonal Atlantic forest formations, and they can play important roles in humid forests.

Regarding syndrome distribution on vertical layers, it was possible to make some conclusions and considerations after the functional groups were formed (see Figure 2): 1) non-flying mammaliochorous groups (G2 and GI1) and groups pollinated preferably by small insects (G1, G2, G3, G4) occurred in all vegetation layers, but especially in the lower vegetation layers; 2) anemochoric (G3.1) and autochoric (G3.2) groups and chiropterocory species were more frequently found in the forest canopy, and the same occurred with regard to pollination by large bees; 3 ) ornitochoric groups (G1, G4), although found in all strata, were dominant in the lower strata. Pollination by very small insects and moths was absent in the canopy and it was observed only in the understory.

The study involved over $90 \%$ of individuals found in the sampled area, and the species evaluated represent about $88 \%$ of total importance value to the community (VALE et al., 2009). This indicates a high representation in the tree community and demonstrates that the method may be replicated in other areas. Aggregation of species into functional groups is used to reduce the complexity of high-diversity ecosystems (HUBBEL, 2005), and it can indicate differences among species which are difficult to detect (GRAAE; SUNDE, 2000) or even reveal functional characteristics of the ecosystem itself (SWAINE; WHITMORE, 1988). This paper adopted an effective methodology which may be replicated in further comparisons. The functional groups identified in the study area were similar to those in other protected seasonal semideciduous forests (VALE et al., 2010), even when more species and characteristics were used, confirming the hypothesis that areas with a good original conservation status present diverse tree plant groups, which are able to provide the native fauna with resources and present a high natural regeneration potential.

\section{Acknowledgments}

The authors thank the Foundation for Research Support of the State of Minas Gerais (FAPEMIG) for financial support.

FIGURE 2: Functional characteristics in different strata in a semideciduous seasonal forest (Araguari, MG, Brazil). The arrows represent the strata where the ecological traits were dominant.

\begin{tabular}{|l|l|} 
Subcanopy \\
mammaliochory (non-flying mammals) \\
pollination by small insects
\end{tabular}




\section{References}

ANTUNEZ, I.; RETAMOSA, E. C.; VILLER, R. Relative growth rate in phylogenetically related deciduous and evergreen woody species. Oecologia, Heidelberg, v. 128, p. 172-180, 2001.

BAWA, K. S.; BULLOCK, S. H.; PERRY, D. R.; COVILLE, R. E.; GRAYUM, M. H. Reproductive biology of tropical lowland rain forest trees II Pollination systems. American Journal of Botany, St. Louis, v. 72, n. 3, p. 346-356, 1985.

BUSSAB, W. O.; MORETTIN, P. A. Estatística básica. 5. ed. São Paulo: Saraiva, 2003. 542 p.

CLARK. C. J.; POULSEN, J. R. The role of arboreal seed dispersal groups on the seed rain of a lowland tropical forest. Biotropica, Maiden, v. 33, n. 4, p. 606-620, 2001.

CORDEIRO, N. J.; HOWE, H. F. Low recruitment of trees dispersed by animals in African forest fragments. Conservation Biology, Washington, v. 15, n. 6, p. 1733-1741, 2001.

CORNELISSEN, J. H. C.; DIEZ, P. C.; HUNT, R. Seedling growth, allocation and leaf attributes in a wide range of woody plant species and types. Journal of Ecology, London, v. 84, n. 5, p. 755-765, 1996.

FELFILI, J. M.; CARVALHO, F. A.; HAIDAR, R. F. Manual para o monitoramento de parcelas permanentes nos biomas Cerrado e Pantanal. Brasília: Universidade de Brasília, Departamento de Engenharia Florestal, 2005. 60 p.

GANDOLFI, S.; JOLY, C. A.; RODRIGUES, R. R. Permeabilityimpermeability canopy trees as biodiversity filters. Scientia Agricola, Piracicaba, v. 64, n. 2, p. 433-439, 2007.

GRAAE, B. J.; SUNDE, P. B. The impact of forest continuity and management on forest floor vegetation evaluated by species traits. Ecography, Lund, v. 23, p. 720-731, 2000.

HOWE, H. F.; SMALLWOOD, J. Ecology of seed dispersal. Annual Review of Ecology and Systematics, Palo Alto, v. 13, p. 201-228, 1982.

HUBBEL, S. P. Neutral theory in community ecology and the hypothesis of functional equivalence. Functional Ecology, London, v. 19, p. 166-172, 2005.

KILLEEN, T.; JARDIM, A.; MANAMI, F.; SARAVIA, P.; ROJAS, N. Diversity, composition, and structure of a tropical deciduous forest in the Chiquitania region of Santa Cruz, Bolivia. Journal of Tropical Ecology, Winchelsea v. 14, p. 803-827, 1998.

KINOSHITA, L. S.; TORRE, R. B.; FORNI-MARTINS, E. R.; SPINELLI, T.; AHN, Y. J.; CONSTÂNCIO, S. S. Composição florística e síndromes de polinização e de dispersão da mata do Sítio São Francisco, Campinas, SP, Brasil. Acta Botanica Brasilica, São Paulo, v. 20, n. 2, p. 313-327, 2006.

KÖPPEN, W. Climatologia, com um estudio de los climas de la tierra. México: Fondo de Cultura e Economia, 1948. 479 p.

KREMEN, C. Managing ecosystem services: what do we need to know about their ecology? Ecological Letters, Paris, v. 8, p. 468479, 2005.

LORD, J. M.; NORTON, D. A. Scale and the spatial concept of fragmentation. Conservation Biology, Washington, v. 4, n. 2, p. 197-202, 1990.

LOPES, S. F.; SCHIAVINI, I.; OLIVEIRA, A. P.; VALE, V. S. An ecological comparison of floristic composition in Seasonal
Semideciduous Forest in Southeast Brazil: implications for conservation. International Journal for Forestry Research, New York, v. 2012, p. 1-14, 2012.

MATLACK, G. R. Plant species migration in a mixed history forest landscape in Eastern North America. Ecology, New York, v. 75, n. 1, p. 1492-1502, 1994.

McCUNE, B.; MEFFORD, M. J. PC-ORD multivariate analysis of ecological data. version 6. Gleneden Beach: MjM Software, 2011.

MÉDAIL, F.; ROCHE, P.; TATONI, T. Functional groups in phytoecology: an application to the study of isolated plant communities in Mediterranean France. Acta Oecologica, New York, v. 19, n. 3, p. 263-274, 1998.

METZGER, J. P. Tree functional group richness and landscape structure in a Brazilian tropical fragmented landscape. Ecological Applications, Ithaca, v. 10, n. 4, p. 1147-1161, 2000.

MORELlATO, L. P. C.; TALORA, D. C.; TAKANASHI, A.; BENCKE, C.; ROMERA, E. C.; ZIPPARRO, V. B. Phenology of Atlantic Rain Forest trees: a comparative study. Biotropica, Maiden, v. 32, p. 811-823, 2000.

OLIVEIRA, P. O.; GIBBS, P. E. Reproductive biology of wood plants in a cerrado community of Central Brazil. Flora, Jena, v.195, p. 311-329, 2000.

OLIVEIRA-FILHO, A. T.; FONTES, M. A. Patterns of floristic differentiation among atlantic forests in Southern Brazil and the influence of climate. Biotropica, Maiden, v. 32, p. 793-810, 2000.

OLIVEIRA-FILHO, A. T.; MELLO, J. M.; SCOLFORO, J. R. S. Effects of past disturbance and edges on tree community structure and dynamics within a fragmento of tropical semideciduous forest in south-easten Brazil over five-year period (1987-1992). Plant Ecology, Dordrecht, v. 131, n. 4, p. 45-66, 1997.

OLIVEIRA-FILHO, A. T.; RATTER, J. A. Vegetation physiognomies and woody flora of the Cerrado Biome. In: OLIVEIRA, P. S.; MARQUIS, R. J. (Ed.). The Cerrados of Brazil. New York : Columbia University Press, 2002. 367 p.

ORIANS, G. H. The number of bird species in some tropical forests. Ecology, New York, v. 50, p. 783-801, 1969.

PEARSON, D. L. Vertical stratification of birds in a tropical dry forest. The Condor, Albuquerque, v. 73, p. 46-55, 1971.

PEARSON, T. R. H.; BURSLEM, D. F. R. P.; GOERIZ, R. E.; DALLING, J. W. Regeneration niche partitioning in neotropical pioneers: effects of gap size, seasonal drought and herbivory on growth and survival. Oecologia, Heidelberg, v. 137, p. 456-465, 2003.

PENDRY, C. A.; DICK, J.; PULLAN, M. R.; KNEES, S. G.; MILLER, A. G.; NEALE, S.; WATSON, M. F. In search of a functional flora-towards a greater integration of ecology and taxonomy. Plant Ecology, Dordrecht, v. 192, p. 161-167, 2007.

PENNINGTON R. T.; LAVIN M.; OLIVEIRA-FILHO, A. T. Woody plant diversity, evolution, and ecology in the tropics perspectives from seasonally dry tropical forests. Annual Review of Ecology, Evolution, and Systematics, Palo Alto, v. 40, p. 437457, 2009.

PETCHEY, O. L.; GASTON, K. J. Functional diversity (FD), species richness and community composition. Ecology Letters, Paris, v. 5, p. 402-411, 2002. 
PIJL, L. V. D. Principles of dispersal in higher plants. 3. ed. New York: Springer-Verlag, 1982. 215 p.

POWERS, J. S.; TIFFIN P. Plant functional type classifications in tropical dry forests in Costa Rica: leaf habit versus taxonomic approaches. Functional Ecology, London, v. 24, b. 4, p. 927-936, 2010.

RICHARDS, P. W. The tropical rain Forest: an ecological study. 2 ed. Cambridge: University Press, 1996. 611 p.

ROTH, I. Stratification of a tropical forest as seen in dispersal types. Dordrecht: W. Junk Publishers, 1987. 324 p.

SANTOS, E. R.; ASSUNÇÃO, W. L. Distribuição espacial das chuvas na microbacia do córrego amanhece, Araguari - MG. Caminhos de Geografia, Uberlândia, v. 6, n. 19, p. 41-55, 2006.

SHEPHERD, G. J. FITOPAC-SHELL: manual do usuário. Campinas: Universidade Estadual de Campinas, 2004. 88 p.

SMITH, A. P. Stratification of temperature and tropical forests. American Naturalist, Chicago, v. 107, n. 957, p. 671- 683, 1973.

SWAINE, M. D.; WHITMORE, T. C. On the definition of ecological species groups in tropical rain forests. Vegetatio, Perth, v. 75, p. 8186, 1998.

TONIATO, M. T. Z.; OLIVEIRA-FILHO, A. T. Variations in tree community composition and structure in a fragment of tropical semideciduous forest in southeastern Brazil related to different human disturbance histories. Forest Ecology and Management, Amsterdan, v. 198, n. 2004, p. 319-339, 2004.
VALE, V. S.; SCHIAVINI, I.; LOPES, S. F.; DIAS NETO, O. C.; OLIVEIRA, A. P.; GUSSON, A. E. Composição florística e estrutura do componente arbóreo em um remanescente primário de floresta estacional semidecidual em Araguari, Minas Gerais, Brasil. Hoehnea, São Paulo, v. 36, n. 3, p. 417-429, 2009.

VALE, V. S.; SCHIAVINI, I.; OLIVEIRA, A. P.; GUSSON, A. E. When ecological functions are more important than richness: a conservation approach. Journal of Ecology and the Natural Environment, Assiut, v. 2, n. 12, p. 270-280, 2010.

WALKER, B. Biodiversity and ecological redundancy. Conservation Biology, Washington, v.6, p. 18-23, 1992.

WALTHER, B. A. Gounded ground birds and surfing canopy birds: variation of foraging stratum breadth observed in neotropical forest birds and tested with simulation models using boundary constraints. The Auk, Albuquerque, v. 119, n. 3, p. 658-675, 2002.

WALTHER, B. A.; CLAYTON, D. H.; GREGORY, R. D. Showiness of neotropical birds in relation to ectoparasite abundance and foraging stratum. Oikos, Copenhagen, v. 87, p. 157-165, 1999.

WILSON, M. F. The ecology of seed dispersal. In: FENNER, M. (Ed.). Seeds: the ecology of regeneration in plant communities. Wallingford: CAB Internacional, 1992. p. 61-85.

YAMAMOTO, L. F.; KINOSHITA, L. S.; MARTINS, F. R. Síndromes de polinização e de dispersão em fragmentos da floresta estacional semidecídua montana, SP, Brasil. Acta Botanica Brasilica, São Paulo, v. 21, n. 3, p. 553-574, 2007. 


\section{Appendix}

Statistical summary of Multi-Response Permutation Procedure with regard to funcional groups in a seasonal semideciduous forest.

\begin{tabular}{lllccc}
\hline & Group Comparisons & & T & A & p \\
\hline G1 & vs. & G2 & -3.827 & 0.239 & 0.004 \\
G1 & vs. & G3 & -7.345 & 0.260 & 0.001 \\
G1 & vs. & G4 & -10.381 & 0.310 & 0.001 \\
G1 & vs. & GI1 & -3.536 & 0.425 & 0.008 \\
G1 & vs. & GI2 & -2.697 & 0.234 & 0.018 \\
G2 & vs. & G3 & -6.084 & 0.272 & 0.001 \\
G2 & vs. & G4 & -8.418 & 0.296 & 0.001 \\
G2 & vs. & GI1 & -2.790 & 0.456 & 0.017 \\
G2 & vs. & GI2 & -2.392 & 0.293 & 0.023 \\
G3 & vs. & G4 & -15.313 & 0.467 & 0.001 \\
G3 & vs. & GI1 & -5.571 & 0.362 & 0.003 \\
G3 & vs. & GI2 & -2.663 & 0.134 & 0.018 \\
G4 & vs. & GI1 & -7.487 & 0.362 & 0.001 \\
G4 & vs. & GI2 & -4.704 & 0.190 & 0.002 \\
GI1 & vs. & GI2 & -1.414 & 0.585 & ns \\
\hline
\end{tabular}

The probablity (p) test was lower than 0.001 , thus the null hypothesis of no difference between the groups was rejected. Only GI1 and GI2 show no statistical difference in pairwise comparisons. 